\title{
Kiss Tibor1: A személyiségi jogok érvényesülése az ügyvédi tevékenység gyakorlása során
}

Debreceni Jogi Mühely, 2012. évi (IX. évfolyam) 4. szám (2012. október) 28-38.

\section{A SZEMÉLYISÉGI JOGOK}

Az elmúlt mintegy két évtizedben a személyiségi jogok a jogalkotás és a jogalkalmazás fókuszába kerültek. Mindez testet öltött az Alkotmánybíróság jogfejlesztő tevékenységében, illetve a bíróságok előtt megszaporodott peres jogvitákban. Sokan, sokféle aspektusból vizsgálták a különböző személyhez füződő jogokat, és azok megsértésének jogkövetkezményeit, különös tekintettel a nem vagyoni kártérítés kérdésére. $^{2}$ A nem vagyoni kártérítéssel kapcsolatos joggyakorlatot feldolgozó legújabb jogirodalom jellemzője, hogy vagy egy érintett sértetti kört (közszereplőt, hozzátartozói igények) helyez a vizsgálódás középpontjába, ${ }^{3}$ vagy a vagyoni kártérítések körében a hátrány bizonyításával kapcsolatos jogalkalmazásbeli anomáliákra világít rá. ${ }^{4}$

Olyan jogterülettel állunk szemben, ahol a törvényi szabályozás alapvetően keret-jellegü, s nemcsak a tipikus jogkövetkezmény, az eszmei kártérítés vonatkozásában - ahogy arra Fézer Tamás egyik tanulmányában szemléletesen rámutat ${ }^{5}$-, hanem a személyiségi jogok alaptörvényi, illetőleg törvényi szintü megfogalmazása kapcsán is. Az egyes személyiségi jogok tartalmát - normatív szabályozás hiányában - a jogalkalmazónak kell feltárnia, azaz a személyiségi jogok sérelme esetén a iudicatura „kelti életre” az elvont jogi fogalmakat. A 2012. január 1-én hatályba lépett Alaptörvény a Szabadság és Felelősség fejezetben - a tényleges tartalom részletes kibontása nélkül - több személyhez füződő jogot nevesít, így az emberi méltóságot, az élethez való jogot, ${ }^{6}$ valamint a szabadsághoz és személyi biztonsághoz füződő jogot, ${ }^{7}$ magán és családi élethez, jóhírnévhez füződő jogot, ${ }^{8}$ személyes adatok védelméhez füződő jogot, ${ }^{9}$ a gondolat, lelkiismeret és vallásszabadsághoz füződő jogot, ${ }^{10}$ valamint a véleménynyilvánítási szabadsághoz és sajtószabadsághoz füződő jogot. ${ }^{11}$

A jelenleg az Országgyülés előtt lévő új Polgári Törvénykönyv ${ }^{12}$ a jelenleg hatályos szabályozáshoz képest a személyiségi jogok tartalmát illetően nem sok eltérést mutat, bár a képmás és hangfelvételhez való jog és különösen a becsülethez füződő jog körében a jogsértés mibenlétének definiálására tesz kísérletet, valamint nevesíti a közéleti szereplök személyiségi jogának védelmét, $s$ új jogintézményként a sérelemdíjban látja a speciális szankcionálás lehetőségét. ${ }^{13}$

Az alábbiakban arra teszünk kísérletet, hogy megvizsgáljuk, hogy egy speciális személyi kör, az ügyvédség, a hivatásának gyakorlása körében hogyan tudja érvényesíteni az Alaptörvényben és a Ptk.-ban is garantált személyiségi jogait, ezeknek milyen korlátjait alakította ki a bírói gyakorlat, és a jogsértésekre adott válaszként milyen adekvát szankciók alkalmazását tartja szükségesnek. A becsülethez és jóhírnévhez füződő jog, illetve a képmás védelméhez füződő jogok azok, amelyek az ügyvédi hivatás gyakorlása során elsődlegesen sérelmet szenvedhetnek, ezért vizsgálódásunkat erre a körre korlátozzuk. Felmerül ennek kapcsán az az alapkérdés, hogy a hivatását gyakorló ügyvéd mennyiben tekinthető közszereplőnek, ugyanis a közszereplők megítélése a személyiségi jogok vonatkozásában speciális. Az elmúlt két évtized bírói gyakorlatában ezen kérdéskör az ügyvédség vonatkozásában szinte egyáltalán nem merült fel, eltekintve attól a döntéstől, mely az ügyvédeket ért sérelem esetén közérdekböl az igazságügy miniszter sajtóhelyreigazítási eljárás indítási jogát deklarálta. ${ }^{14} \mathrm{E}$ körben említhető továbbá azon eseti döntés is, mely elsősorban az ügyvédek, de más személyek vonatkozásában is általános 
jelleggel mondja ki, hogy valamely hatóság elötti eljárásnak a kezdeményezése, büntetőfeljelentés megtétele önmagában nem ad alapot személyiségvédelmi per megindítására akkor sem, ha az eljárás során tett nyilatkozatok nem minősülnek valónak, feltéve, hogy a tényállítások indokolatlanul nem sértőek, bántóak, illetőleg durván sértő kifejezést nem tartalmaznak. ${ }^{15}$

Az utóbbi pár év továbbra is szükkörü bírói gyakorlatának és ellentmondásainak bemutatására helyezzük a hangsúlyt a továbbiakban, rávilágítva az ügyvédi tevékenység specialitásaiból fakadó egyedi jogi megoldásokra.

\section{AZ ÜGYVÉDI TEVÉKENYSÉG}

Az ügyvédekröl szóló törvényi szabályozás ${ }^{16}$ általános jelleggel rögzíti, hogy az ügyvéd a hivatásának gyakorlásával megbízója jogainak érvényesítését és kötelezettségeinek teljesítését segíti elő törvényes eszközökkel és módon, továbbá közremüködik abban, hogy az ellenérdekű felek a jogvitáikat megegyezéssel intézzék el. Általános elvként rögzíti továbbá a törvény, hogy az ügyvéd tevékenységében szabad és független, nem vállalhat olyan kötelezettséget, amely a hivatásbeli függetlenségét veszélyezteti. ${ }^{17}$

Az ügyvéd számtalan tevékenységet láthat el, így ügyfelet képvisel polgári perben, büntetőügyben védelmet lát el, valamint különböző szerződéseket, beadványokat és egyéb iratokat készít, jogi tanácsokat ad. Az első két helyen említett tevékenység az, amely nyilvánosság előtt zajlik, s ezért fokozottabban merülhet föl annak lehetősége, hogy az ügyvéddel szemben, az ügyvéd sérelmére személyhez füződő jogokat sértő magatartást tanúsítanak. Fundamentális kérdésként fogalmazódik meg, hogy az ügyvéd tekinthető-e közszereplőnek, ugyanis a kialakult bírói gyakorlat fokozottabb türési kötelezettséget ír elő a közszereplőkkel szemben, a közszereplők vonatkozásában a személyiségi jogok védelme sajátos értelmezést kap. Először ezért a közszereplői minőséget szükséges definiálni.

\section{AZ ÜGYVÉD, MINT KÖZSZEREPLŐ}

Az állandóan követett bírói gyakorlat szerint a közszereplő magatartásának értékelése, bírálata nem alapozhatja meg jogsértés megállapítását. ${ }^{18}$ Az Alkotmánybíróság a 36/1994. (VI.24.) AB határozatában rögzítette, hogy a közszereplők fokozottabban bírálhatók, a közszereplést vállaló személynek vállalnia kell azt is, hogy a közvélemény figyelemmel kíséri tevékenységét és nagyobb türelmet kell tanúsítania a kritikai megnyilvánulásokkal szemben. „A demokratikus jogállam jellemzöje a közszereplők fokozott bírálata."19 „A gyakorlat szerint a közszereplöknek lényegesen többet kell elviselniük hírnevük, becsületük, emberi méltóságuk vonatkozásában." 20

A jogirodalom is ezen álláspontot foglalja el: „A plurális politikai környezet természetes módon megnövelte a nyilvános közszereplök (elsösorban politikusok) kritikáját. A nyilvánosság funkciója teljesül a kritika gyakorlásával. A strassburgi gyakorlat (azaz az Európai Emberi Jogi Bíróság gyakorlata), amely lényegesen kevesebb védelmet nyújt a közélet szereplöinek, a magyar gyakorlat részévé vált. Kivételt olyan közlések jelentenek, mint visszataszitó állatokhoz (férgek, patkány) való hasonlitás, vagy lefasisztázás, illetve a magánélet súlyos, az emberi méltóságot is sértő támadása. "21

A fentieket tükrözi vissza az állandóan követett magyar bírói gyakorlat is, mely szerint a közszereplőkről alkotott kedvezőtlen véleménynyilvánítás, értékítélet önmagában akkor sem alapoz meg személyiségvédelmet, ha túlzó vagy felfokozott érzelmeket tükröz. A közélet szereplőinek pedig el kell viselniük a személyüket kedvezőtlen színben feltüntető és tevékenységüket negatív módon értékelő véleményt, kritikát is. ${ }^{22}$ 
A közszereplök fokozott bírálhatósága azonban nem jelenti azt, hogy a közszereplő ne léphetne fel a személyét érintő valótlan és tevékenységét kedvezőtlen színben (hamisan) bemutató kijelentések miatt. A bírói gyakorlat szerint ugyanis valótlan és hátrányos megítélés kiváltására alkalmas tényállítás esetén a közszereplő ugyanolyan feltételekkel jogosult személyiségi jogvédelemre, mint bármely más személy. ${ }^{23}$

A jogirodalom is egyetért azon bírói gyakorlattal, mely a közéleti szereplők, politikusok személyhez füződő jogának megsértését is megállapíthatónak találja közéleti tevékenységükkel összefüggésben is. A Fővárosi Bíróság rámutatott arra, hogy ,a véleménynyilvánitás szabadsága nem terjed ki a tudatosan valótlan tényállitásokra, amelyek közlésére a közlö fél gondatlansága miatt került sor. A közvélemény tájékoztatásához fontos társadalmi érdek füzödik, azonban ez azt jelenti, hogy a tájékoztatás során a valóságot kell feltárni, azaz az azt alátámasztó hitelt érdemlö bizonyitékokkal és nem úgy, mint ahogy az eset kapcsán történt.",24

Tattay Levente egyik monográfiájában ugyancsak idézi a Legfelsőbb Bíróság joggyakorlatát (Pfv.E.20.885/2003. számú eljárás alapján), mely szerint téves azon álláspont, hogy a véleménynyilvánítás személyhez füződő jogot nem sérthet, illetve, hogy a közszereplő „türési kötelezettségét” kijelentései nem léphetik túl. A közszereplő sem köteles türni személyhez füződő jogai megsértését és a Ptk. 75. §-a (1) bekezdése alapján a közszereplők személyhez füződő jogait is köteles mindenki tiszteletben tartani. ${ }^{25}$

Arra vonatkozóan azonban már kevés a jogirodalmi és bírói gyakorlati útmutatás, hogy ki tekinthető közszereplőnek. A bírói gyakorlat szerint azt a kérdést, hogy a személy közszereplőnek tekinthető-e, nem általában az adott személy pozíciója, hivatali beosztása, közéleti státusza, vagy bármely okból fennálló szélesebb körü ismertsége, hanem a jogi megítélés szempontjából releváns, konkrét élethelyzet alapján kell megítélni. ${ }^{26}$ Abban egységes a bírói gyakorlat, hogy a politikusokat közszereplönek tekintik, ${ }^{27}$ ugyancsak közszereplőként határozza meg az újságírókat is, rámutatva arra, hogy a szabad véleménynyilvánítás olyan alkotmányos alapjog, amely csak felelősséggel gyakorolható, és a valótlan tények közlésének elkerülése érdekében bizonyos kötelezettségekkel jár a közvélemény alakításában hivatásszerüen részt vevő személyek esetében. ${ }^{28}$

Az elmúlt rendszer titkosszolgálati tevékenységének feltárásáról és az állambiztonsági szolgálatok történeti levéltára létrehozásáról szóló 2003. évi III. törvény 1. §-a (2) bekezdésének 13. pontja a közszereplőt akként definiálja, hogy az az a személy, aki közhatalmat gyakorol, gyakorolt, vagy közhatalom gyakorlásával járó tisztségre jelölték, illetve aki a politikai közvéleményt feladatszerüen alakítja, vagy alakította. E törvény speciális tárgyi hatályánál fogva - viszonylag szük körben határozza meg a közszereplö fogalmát, mely alá az ügyvédek nyilvánvalóan nem sorolhatók közhatalom-gyakorlás hiányában.

A fentiekben már hivatkozott alkotmánybírósági határozaton túlmenően a jogirodalom szerint is közszereplésnek az a megnyilvánulás minősül, amely befolyásolja a szükebb, vagy a tágabb társadalom életét, a helyi vagy az országos viszonyok alakulását. A társadalom tagjai igénylik, hogy a közéleti szereplök közéleti tevékenységét megismerjék, ezért a közszereplés elválaszthatatlan a nyilvánosságtól. ${ }^{29}$

Ezen definíció hatálya alá tartozhatnak az ügyvédek, különös tekintettel a nagyobb közérdeklődésre számot tartó bírósági eljárásokban fellépő jogi képviselők, illetőleg védők. Megítélésünk szerint ugyanakkor a közszereplöi minőség kérdésében csak a konkrét tényállás ismeretében, a konkrétan kifejtett tevékenység ismeretében lehet állást foglalni, azaz lehetnek olyan esetek, amikor egy ügyvéd közszereplőnek minősülő tevékenységet fejt ki, illetve olyan megnyilvánulásai is, amelyek nem minősíthetők 
közszereplésnek. ${ }^{30}$ Nem véletlen az sem, hogy az új Ptk. szövegjavaslata sem tesz kísérletet arra, hogy általános jelleggel megfogalmazza a közszereplői minőséget.

A polgári perben jogi képviseletet ellátó ügyvédet a bíróság nem minősíti „klasszikus értelemben" vett közszereplönek, mert a közhatalom gyakorlásában nem vesz részt, illetőleg a közvélemény befolyásolására nem törekszik. ${ }^{31}$ A nyilvános bírósági eljárásban (tárgyaláson) jelenlévők közül a bíróság tagjai közszereplőnek minősülnek, ugyanakkor arra mutat rá egy legújabb bírósági határozat, hogy még egy nyilvános tárgyaláson történő ügyvédi képviselet ellátás sem tekinthető nyilvános közszereplésnek. ${ }^{32}$ Ez a megközelítés egyértelmúen a közhatalom-gyakorláshoz köti a közszereplöi mivoltot.

A fentiekre figyelemmel az ügyvéd közszereplői minőségét és az ügyvédeket ért személyiségi jogi jogsértéseket konkrét bírósági döntéseken keresztül vizsgáljuk a továbbiakban:

\section{BECSÜLETHEZ ÉS JÓHÍRNÉVHEZ FÜZŐDŐ JOG}

A Ptk. 76. §-a alapján a személyhez füződő jogok sérelmét jelenti a becsület megsértése. A becsület a személyről a társadalomban kialakul értékítélet, amelynek kedvezőtlen megváltozása jelenti a becsület sérelmét. Az általánosan elfogadott jogirodalmi álláspont és az egységesen követett bírói gyakorlat szerint becsületsértőnek az a kijelentés tekinthető, amely - függetlenül annak tartalmára és a tartalom valóságára - aránytalanul túlzó, indokolatlanul bántó, lealázó, lekicsinylő, lealacsonyító, vádaskodó. ${ }^{33}$ Bármilyen személyiséget érintő közlés tehát abban az esetben alkalmas a becsület megsértésére, ha az kifejezetten pejoratív, az általános értékítélethez képes túlzóan negatív színben tüntet fel valakit. E körben az adott kijelentés esetleges, a valóságnak meg nem felelő volta irreleváns.

A becsület a jóhírnév fogalmánál is szűkebb körü. A becsület a személy társadalmi megítélését, megbecsülését, egyéni értékeinek elismerését jelenti, amely megköveteli, hogy a személyt lehetőleg tényleges, valóságos értékének megfelelően értékeljük. A becsület a természetes személyhez kötődik. ${ }^{34}$

Hasonlóan fogalmaz a becsület védelméhez füződő személyiségi jog kapcsán Székely László is: „A másik ember becsületéröl vagy becsületének hiányáról tett megállapitás lényegét tekintve értékitélet. ... A becsület megsértése akkor következik be, ha a kifejezésre juttatott értékitélet nem felel meg az itéletalkotás közmegegyezés által elfogadott törvényeinek, logikai szabályainak (pl.: X nyilvánvalóan gazember, hiszen barna sapkát hord!). Ha a véleményt alkotó megsérti az itéletalkotás előbb emlitett szabályait, az általa fogalmazott értékelés torz, következetlen, túlzó, indokolatlanul bántó, lealacsonyitó, becsmérlö, vádaskodó, stb. lesz. "35

A bírói gyakorlat szerint is a személy becsületét, emberi méltóságát sérti az a vélemény, illetőleg bírálat, amely a kifejezésmódjában indokolatlanul bántó, megalázó. ${ }^{36} \mathrm{~A}$ judikatúra arra az álláspontra helyezkedett, hogy amennyiben a vélemény, bírálat vagy értékítélet indokolatlanul sértő vagy lealázó, az a becsület vagy az emberi méltóság megsértésének megállapítását alapozza meg. ${ }^{37}$

Rámutat ugyanakkor az ügyvédi tevékenység kapcsán arra is a Fővárosi Bíróság, hogy nem lehet figyelmen kívül hagyni azt a tényt, hogy az ügyvédként eljáró személynek számolnia kell azzal, hogy egy adott perben vele szemben álló álláspontot képviselő fél a tevékenységét kritizálhatja, vele ellentétes álláspontot fejt ki egészen odáig menően, hogy alapvetően kérdőjelezik meg álláspontjának hitelességét. ${ }^{38}$ Ezen bírósági értelmezés pedig ugyancsak azt erősíti, hogy az ügyvéd tevékenységét kritikával illető kijelentéseket 
véleményként kell értékelni, nem pedig tényállításként, amiből következik az is, hogy személyiségi jogsértés megállapítására csak szük körben kerülhet sor.

A Ptk. 78. §-a (1) bekezdése szerint a személyhez füződő jogok védelme kiterjed a jóhírnév védelmére is. A (2) bekezdés szerint a jóhírnév sérelmét jelenti különösen, ha valaki más személyére vonatkozó, azt sértő, valótlan tényt állít, híresztel vagy való tényt hamis színben tüntet fel.

A jóhírnév az a társadalmi, közéleti, gazdasági ismertség, mely az adott személyre nézve kedvező. ${ }^{39}$ Törő Károly szerint a hírnév általában a személyre vonatkozó, a személyiséget érintő ismereteket jelenti. Ezért a személyiség érvényesítésének, a személy megkülönböztetésének az eszköze. Sajátossága, hogy a megkülönböztetés nem formális jelekkel történik, hanem tartalmilag, a személy tetteinek, magatartásának, tevékenységének, körülményeinek a kifejezésre juttatásával. A személy hírnevét azok az adatok, értesülések, ténymegállapítások alakítják, amelyek bizonyos személyre vonatkoznak és alkalmasak a társadalmi értékelésen alapuló megkülönböztetésre. A hírnév a társadalmi gyakorlatban keletkezik, a társadalom tagjainak tudatában él, létezik, tehát emberi tudattartalom. ${ }^{40}$

A jóhírnév sérelme akkor valósul meg, ha: (i) más személyt érintő, (ii) valótlan tartalmú vagy a valóságot hamis színben feltüntetö, (iii) olyan közlés történik, amely objektíve sérelmek okozására alkalmas.

A jóhírnév megsértése megállapításának nem feltétele a közlés eredménye, az érdeksérelem tényleges bekövetkezése. „Nem kell vizsgálni, hogy a közlés hatására ténylegesen hogyan változott meg a személy társadalmi értékelése. ...A hírnévrontás megállapításához a hírnév sérelmére objektive alkalmas valótlan (a valóságot hamis színben feltüntetö) tényállitás mellett nincs szükség további különös érdeksérelem megvalósulására ... Nincs jelentösége a személyiséget ért sérelem súlyának sem. ... A kisebb súlyú személyiségi sérelmet sem lehet orvoslás nélkül hagyni. "41

A bíróságok az ügyfeleit különböző polgári peres eljárásokban képviselö ügyvédet az ellenfél által hazugnak nevező kifejezés kapcsán több határozatot is hoztak, vizsgálva a becsülethez és a jóhírnévhez füződő jog sérelmét.

A bírósági gyakorlat abban egységes, hogy nem kizárólag a jóhírnévhez füződő jog megsértése, hanem a becsülethez füződő jog védelme körében is meg kívánja a valóság bizonyítását még olyan esetben is, amikor indokolatlanul túlzó, bántó, illetve lekicsinylő kifejezések használatáról van szó, ellentétben azon fentebb citált általános gyakorlattal, mely ilyen esetben a kijelentést túlzó véleményként értékelve szankció alkalmazását tartja szükségesnek. Az ugyanakkor megállapítható, hogy a szélsőségesen, indokolatlanul bántó, sértő kifejezésmódot - ha a kifejezések az ügyvédi tevékenységet érintik - véleményként is jogsértőnek tartja a bírói gyakorlat abban az esetben, ha a használt kifejezések olyan magatartásokra utalnak, amelyek nyilvánvalóan ellentétesek az ügyvédi törvény rendelkezéseivel és az ügyvédi etika alapvetö szabályaival. E körben a „mértéktelen hazudozó”, „gátlástalan” kifejezéseket tekintette mind jóhírnevet, mind becsületet sértő kifejezéseknek a bíróság. ${ }^{42}$

Azon kijelentések tekintetében, amelyek az ügyvéd tevékenységét olyan jelzőkkel illetik, melyek felvetik büncselekmény elkövetésének lehetőségét - így a „titkosszolgálati kapcsolatokat felhasználva jutott információhoz”, illetőleg ,adatokat hamisított” kijelentések vonatkozásában arra a következtetésre jutott a bíróság, hogy ezek ugyancsak alkalmasak az ügyvéd becsülethez füződő jogának megsértésére. ${ }^{43}$ 
Egy másik ítéletében ezzel szemben a Fővárosi Bíróság arra mutatott rá, hogy az ügyvéd tevékenységét „hazudozó ügyvéd” kifejezéssel illető személy nem követett el személyhez füződő jogsértést, nem sértette meg az ügyvéd becsület védelméhez füződő jogát, mert úgy ítélte meg a lefolytatott bizonyítás adatai alapján, hogy az alperes meg tudott jelölni olyan peres szituációt, melyből alappal vonhatott le a kifejezést használó ilyen következtetést az ügyvéd tevékenységére vonatkozóan. Ennek alapján arra következtetésre jutott mind az első, mind a másodfokú bíróság, hogy a „hazudozó” kifejezés használata nem valósít meg alaptalan gyalázkodást, ezen kifejezés használatát az ügyvédnek türnie kell. ${ }^{44}$

A fentiekben hivatkozott két ítélet összevetéséből megállapítható tehát az a következetlenség, amely ugyanazon kifejezés („hazudozás”) kapcsán egyik esetben lehetővé tette a valóság bizonyítását és annak alapján arra a következtetésre jutott, hogy a kifejezés használata nem jogsértő, míg a másik esetben véleményként minősítve ugyanezen kijelentést azt indokolatlanul túlzónak és becsmérlőnek ítélve a jogsértést megállapította, mellőzve a valóság bizonyítását.

Ez a problémakör visszavezet ahhoz a személyiségi jogi perekben kulcsfontosságú kérdéshez, hogy egy adott kijelentést mely esetben tekinthetünk tényállításnak és mely esetben véleménynyilvánításnak. A Legfelsőbb Bíróság 12. számú polgári kollégiumi állásfoglalása szerint ugyanis a véleménynyilvánítás, értékelés, bírálat miatt jogsértés megállapításának nincs helye. A legújabb bírói gyakorlat ugyanakkor megpróbál különbséget tenni a tényállítás és a véleménynyilvánítás között, megállapítva, hogy az elhatárolás az úgynevezett bizonyíthatósági teszt alapján történhet, azaz az a közlés, amelynek valósága, vagy valótlansága bizonyítható, az ténynek minősül, amelynek valóságtartalma nem bizonyítható, az vélemény. ${ }^{45}$

Álláspontunk szerint téves, a következetes gyakorlattal ellentétes döntést hozott mind az első, mind a másodfokon eljárt bíróság akkor, amikor a „hazudozó” kifejezés használatát nem tekintette jogsértőnek egy, a kifejezést használó személy szubjektív benyomása és értelmezése szürőjén megvilágított, ellentmondásokkal tarkított konkrét esemény kapcsán. Akkor kiszámítható egy ítélkezési gyakorlat, ha ugyanazon kijelentéseket azonos módon ítél meg és vagy minden esetben szükségesnek tartja a valóság bizonyítását, vagy véleményként értékeli ugyanazon kijelentést, amelynek kapcsán legfeljebb annak túlzottan sértő jellegét vizsgálhatja. A probléma az ítélkezési gyakorlatban alapvetően arra vezethető tehát vissza, hogy egyszer véleményként, másszor tényállításként ítél meg ugyanazon kijelentéseket, de az ellentmondás oka megítélésünk szerint nem az ügyvédi tevékenység specialitásában keresendő.

\section{KÉPMÁS VÉDELMÉHEZ FÜZŐDŐ JOG}

Alapvetően az ügyvéd közszereplöi minőségével, vagy éppen annak hiányával függ össze az is, hogy a nyilvános bírósági tárgyaláson történő ügyvédi tevékenység kifejtése, azaz a hivatása gyakorlása közben történő fénykép, illetőleg kép, továbbá videó és hanganyag készítése engedélyköteles-e az ügyvéd részéről, avagy felvételek szabadon készíthetők és közzétehetők ilyen helyzetben. A bírói gyakorlat ugyanis abban a kérdésben egyértelmüen foglal állást, hogy a közszereplőnek a képmása a közszereplésével (de csak azzal) összefüggésben, a közéleti megnyilvánulásai által meghatározott keretben, annak bemutatására használható fel az érintett hozzájárulása nélkül. ${ }^{46}$

Ugyancsak nem sért személyiségi jogot, képmáshoz való jogot a közszereplöről készült, karikatúrának minősülő fényképfelvétel nyilvánosságra hozatala, feltéve, hogy a véleménynyilvánítás ezen formája nem indokolatlanul bántó, sértő, vagy lealacsonyító. ${ }^{47}$ 
A fentiek alapján azt szükséges megvizsgálni, hogy hogyan tekint a bírói gyakorlat arra a helyzetre, amikor az ügyvéd egy peres eljárás során nyilvános bírósági tárgyaláson képviseli ügyfelét. Az ilyen ügyvédi tevékenység-ellátás közszereplésnek minősül-e, avagy sem, s ezért a felvétel készítéshez és közzétételhez az ügyvéd hozzájárulására van-e szükség.

A kérdés megválaszolásához elsődlegesen a jogszabályi háttér megvilágítása szükséges.

A Ptk. 80. §-a (1) bekezdése szerint a személyhez füződő jog megsértését jelenti a más képmásával kapcsolatos bármiféle visszaélés. Ugyanezen szakasz második bekezdése szerint a képmás nyilvánosságra hozatalához - a nyilvános közszereplés kivételével - az érintett személy hozzájárulása szükséges.

A Polgári Perrendtartás ${ }^{48}$ (Pp.) 2008. július 1-től hatályos külön rendelkezéseket tartalmaz a bírósági tárgyalásokon történő felvételkészítésre. Ezen szabályok szerint a nyilvános tárgyaláson a bíróság által meghatározott módon időbeli korlátozás nélkül készíthető kép-, illetőleg hangfelvétel oly módon, hogy a nyilvános tárgyaláson a bíróság tagjairól és a jegyzőkönyvvezetőről, továbbá az ügyészröl a sajtó kép-, illetőleg hangfelvételt készíthet. ${ }^{49}$

A Pp. szabályai értelmében az ügyész kivételével a felekről és más perbeli személyekről, ezek képviselőiről, továbbá a tanúról, a szakértőről, a tolmácsról, és a szemletárgy birtokosáról csak kifejezett hozzájárulás esetén készíthető kép-, illetőleg hangfelvétel. Szükség esetén a bíróság a személyeket a kép-, illetve hangfelvétel készítéséhez való hozzájárulásról megnyilatkoztatja. Ennek megtörténtét, valamint a nyilatkozat tartalmát a jegyzőkönyvben fel kell tüntetni. Ugyancsak speciális szabályozás, hogy az állami vagy helyi önkormányzati feladatot, valamint jogszabályban meghatározott egyéb közfeladatot ellátó, a feladatkörében eljáró személyről hozzájárulása nélkül is készíthető kép-, illetve hangfelvétel. ${ }^{50}$ A perbeli személyek, illetőleg ezek képviselöi, továbbá egyéb közremüködők személyhez füződő jogainak védelméröl a tárgyaláson a rendfenntartás keretében az elnök köteles gondoskodni. ${ }^{51}$

A fentiekből levonható az a következtetés, hogy az ügyvédet, mint peres képviselőt nem tekinti közszereplőnek a jogalkotó, még akkor sem, ha egy nyilvános tárgyaláson lép fel, így a felvétel készítést, közzétételt az engedélyéhez köti. Az a furcsa helyzet áll tehát elö, hogy bár a Ptk. 84. §-a (2) bekezdése szerint a nyilvános közszereplésen készült felvétel nyilvánosságára hozatalához az érintett személy hozzájárulására nincs szükség, a nyilvános bírósági tárgyalást maga a $\mathrm{Pp}$. is csak a bíróság, illetőleg az ügyészség tagjai vonatkozásában tekinti nyilvános közszereplésnek, míg a tárgyaláson résztvevő egyéb személyek, így az ügyvédek tekintetében nem. Ez a törvényi szabályozás álláspontunk szerint hosszú távon nem tartható fenn, ugyanis egy adott nyilvános eseményt nem lehet az azon részt vevők személye szempontjából különböző módon megítélni, és bizonyos részt vevők szempontjából nyilvános közszereplésnek, más szereplők vonatkozásában pedig nem közszereplésnek minősíteni. Indokoltnak tartjuk a Pp. olyan módosítását, amely a nyilvános tárgyaláson részt vevő, szakmáját, hivatását gyakorló személyek egységes megítélését írja elő, s mivel a bíróság és az ügyészség tagjai közhatalmat gyakorolnak, így közszereplőnek minősülnek, a nyilvános tárgyaláson eljáró ügyvédek közszereplőnek minősítése is indokolt lehet. Nem tartunk helyesnek olyan megközelítést sem, mely csak egyes kiemelt, fokozottabb közérdeklődésre számot tartó ügyben (perben) fellépő ügyvédet nyilvánít közszereplőnek, mert az ügyvéd minden esetben jogszabályok értelmezéséből leszürt jogi álláspontot artikulál, így a közvéleményre gyakorolt hatása azonos minden egyes jogvitában. 
Addig azonban, amíg a Pp. fentebb idézett szabályai vannak hatályban, ezekre tekintettel kell megítélni az eljáró bíróságoknak is a nyilvános bírósági tárgyalásokon eljáró ügyvédek képmás védelméhez füződő jogainak védelmét. A bírói gyakorlat már a Pp. fent hivatkozott szabályainak jogrendbe iktatását megelőzően is arra az álláspontra helyezkedett, hogy a bírósági ügy résztvevőiről filmfelvétel csak a tanács elnökének engedélyével készíthető, a tanács elnöke is csak akkor engedélyezheti a képmás rögzítését és nyilvánosságra hozatalát, ha ehhez az érintett személy maga is hozzájárul, feltéve, hogy a hozzájárulása egyértelmü és kifejezett. ${ }^{52}$

A jelenleg hatályos perrendtartási rendelkezésekre is figyelemmel ugyancsak egységes bírói gyakorlat bontakozott ki az ügyvédek képmás védelméhez füződő joga megítélése kapcsán, kimondva azt, hogy nem minősül nyilvános közszereplésnek, ha az ügyvéd egy nyilvános bírósági tárgyaláson lát el képviseletet, s ezért a fényképfelvételek készítéséhez és közléséhez az érintett személy hozzájárulására van szükség. Rámutat a bírói gyakorlat arra, hogy a sajtó munkatársainak kötelessége, hogy amennyiben valakit egyedileg azonosítható módon ábrázol ügyvédként, akkor a készítéshez és a kép felhasználásához is engedélyt kérjen. ${ }^{53}$

Nem minősül a fényképfelvétel készítéséhez való hozzájárulásnak az sem, ha esetleg a tárgyaláson beszédet tartó ügyvéd a vakuvillanást észleli, ugyanis a hozzájárulás ilyen esetben nem egyértelmüen minősíthető ráutaló magatartásnak, hiszen a tárgyaláson eljárva az ügyvéd az ügyfelet képviselve nem elsősorban a képmása védelmével van elfoglalva, sem pedig azzal, hogy a sajtó munkatársainak tevékenységét figyelje. ${ }^{54}$ Felmerülhet ugyanakkor a tárgyalást vezető tanácselnök felelössége, akire a Pp. a személyiségi jogok védelmére vonatkozó kötelezettséget ró. Ha a tanácselnök észleli, hogy a sajtó munkatársai a hivatását gyakorló ügyvédröl - előzetes engedély nélkül - felvételeket készít, és ezt nem akadályozza meg, álláspontunk szerint ezen magatartásával maga is személyiségi jogsértést valósít meg.

A Fővárosi Ítélőtábla is megerősíti, hogy a bírósági tárgyalás olyan nyilvános esemény, melyen részt vevő jogi képviselő meghatározott cél elérése érdekében, munkavégzésének keretében jelenik meg. A nyilvános bírósági tárgyalásról való tudósításhoz szánt illusztráció céljából készített fényképfelvétel kapcsán mind az elkészítéshez, mind a felhasználáshoz az ügyvéd, mint a tárgyalás résztvevője hozzájárulását kell, hogy kérje a sajtó, hiszen az ilyen eseményröl készült fényképfelvételen látható ügyvéd feladata, személye alapján azonosítható, bemutatása külön súlyt ad a képes beszámolónak, az ügyvéd nemcsak passzív szemlélője egy tőle függetlenül zajló eseménysornak.

Arra is rávilágít az ítélőtáblai gyakorlat, hogy a tárgyalás nyilvánossága garanciális szempontból fontos kritérium és föszabályként nem a felek akaratának a függvénye. Nem vethető össze ez a szituáció egy olyan nyilvános eseménnyel, melyen számosan megjelennek, azonban tevékenységük, szándékuk egy fényképfelvételről nem ismerhető fel, megjelenésükből csak az érdeklödésükre, támogatásukra lehet következtetni. A nyilvánosság ilyen esetekben nem garanciális szempont, hanem a minél szélesebb részvétel biztosítása. ${ }^{55}$

A jelenlegi jogszabályi környezet alapján alapvetően elfogadható az a bírósági gyakorlat, amely a nyilvános bírósági tárgyalásokat az ügyvéd szemszögéből nem tekinti olyan nyilvános közszereplésnek, ahol történő ügyvédi fellépés a sajtó által kép- és hangfelvételek formájában szabadon dokumentálható lenne. A bírósági gyakorlat tulajdonképpen arra az álláspontra helyezkedik, hogy a nyilvános bírósági tárgyalás alapvetően különbözik más nyilvános eseményektöl, az igazságszolgáltatás tevékenységének fokozott társadalmi ellenőrzése indokolja csak a tárgyalóteremben a 
nyilvánosságot, a nyilvános bírósági tárgyalás erre tekintettel, $-\mathrm{s}$ ebböl következően csak az igazságszolgáltató hatalom gyakorlásában részt vett bírók szempontjából minősül nyilvános közszereplésnek. A fentiekben kifejtettekkel összhangban ezen a gyakorlaton csak egyértelmü törvényi szabály-változás esetén lehet és indokolt változtatni.

\section{NEM VAGYONI KÁRTÉRÍTÉS}

Az ügyvéd személyhez füződő jogainak megsértésével összefüggésben alkalmazásra kerülő jogkövetkezmények, mint erkölcsi elégtételt nyújtó, a Ptk. 84. §-a (1) bekezdés a) c) pontjában meghatározott jogkövetkezményeken (a jogsértés tényének megállapítása és a jogsértés abbahagyásának követelése, valamint nyilatkozattal történő elégtételadás) túlmenően külön kérdésként merül föl, hogy a személyhez füződő jog megsértésével összefüggésben nem vagyoni kártérítésre igényt tarthat-e az ügyvéd. E körben annak vizsgálata szükséges, hogy az ügyvédet érhetik-e olyan hátrányok, amelyek csak pénzbeli kompenzációval enyhíthetőek, $\mathrm{s}$ ha igen, ezen hátrányok miben ölthetnek testet.

A 34/1992 (VI.1.) AB határozatban az Alkotmánybíróság úgy fogalmazott, hogy a pénzbeli kártérítésnek a nem vagyoni károknál az a funkciója, hogy az elszenvedett sérelem hozzávetőleges kiegyensúlyozásáról olyan vagyoni szolgáltatás nyújtásával gondoskodjon, amely az elszenvedett sérelemért körülbelül egyenértékü másnemü előnyt nyújt. A nem vagyoni kár és kártérítés megállapításának elsődleges feltétele ebből következően az, hogy a felperest érje egyáltalán valamilyen sérelem, amely pénzre konvertálva kiegyensúlyozható.

A bírói gyakorlat ${ }^{56}$ szerint a jogsértéssel okozati összefüggésben nem vagyoni kártérítés megítélésére nemcsak akkor van lehetőség, ha a sérelmet szenvedett személy tételesen igazolja nem vagyoni hátrányait, a bíróság ugyanis a Pp. 163. §-a (3) bekezdése alapján külön bizonyítás nélkül elfogadhatja az olyan hátrány bekövetkeztét, amely köztudomású ténynek tekinthető.

Fölmerül a kérdés, hogy az ügyvédet ért hátrányok vonatkozásában csak a szakmai, hivatásbeli hátrányok, vagy az ügyvédet, mint magánszemélyt ért hátrányok is kompenzálásra kerülhetnek kártérítés formájában.

Abban egységes a bírói gyakorlat, hogy az ügyvédet a tevékenységével összefüggésben ért hátrányok miatt a nem vagyoni kártérítés megilleti, hiszen az ügyvédi tevékenység egyik legfontosabb eleme az ügyvéd személyébe vetett bizalom. Ezen bizalmat ingatja meg az ügyvédről tett alaptalan, s különösen sértő jelentések sokasága, ${ }^{57}$ amely miatt a pénzbeli kompenzáció indokolt.

Az egységesnek nevezhető bírói gyakorlat szerint a becsülethez füződő jog megsértése esetén körülbelül 500.000,- forint, képmáshoz füződő jog megsértése vonatkozásában 150.000,- forint nem vagyoni kártérítést meghaladó mértékủ szankció alkalmazása nem indokolt. Mindez azt is jelenti, hogy a kialakuló gyakorlat egyfajta tarifát alkalmaz, melynél háttérbe szorul a tényleges egyedi hátrányok vizsgálata, $\mathrm{s}$ előtérbe kerül azon megközelítés, hogy az ügyvédi tekintélyen esett csorba - a sérelem jellegétől nagyrészt függetlenül - egy „objektíven” meghatározható, szinte minden jogsértésre egyformán alkalmazható összeggel kompenzálható. Ez a szemlélet azonban a kártérítési dogmatikai szempontokat háttérbe szorítja, $\mathrm{s}$ előre vetíti a sérelemdíj irányába való elmozdulást már a tételes, pozitív jogi szabályozást megelőzően.

Érdekes ugyanakkor az is, hogy nemcsak az ügyvédi tevékenység kapcsán keletkező hátrányok, hanem az ügyvédet, mint magánszemélyt ért sérelmeket is kompenzálhatónak tartja kártérítéssel a bíróság abban az esetben, ha az ügyvéd személyiségének egyébként 
meghatározó eleme, hogy képmásának felhasználását prevenciózusan nem engedélyezi. Ilyen esetben a szükebb családi, baráti körben ért, az engedély nélkül készített fénykép közlésével járó kellemetlenségeket, személyes sértettséget egyfajta sérelemdíjnak is tekinthető nem vagyoni kártérítéssel tartja reparálhatónak a bíróság. ${ }^{58} \mathrm{~A}$ kártérítési szankció indoka ez esetben nem kizárólag az ügyvédi tevékenységben, hanem az ügyvéd, mint magánszemély személyiségében keresendő.

\section{KONKLÚZIÓ}

A hatályos magyar jogszabályi rendelkezések és a bírói gyakorlat áttekintése alapján egyértelmüen levonható néhány következtetés, így az, hogy

- az ügyvéd foglalkozásának, hivatásának gyakorlása körében sem tekinthető általános jelleggel közszereplőnek,

- még egy nyilvános tárgyaláson való fellépés sem valósít meg jogi értelemben vett olyan nyilvános közszereplést, amely miatt a személyhez füződő jogok korlátozhatók lennének,

- az alapvető személyiségi jogok, jóhírnév, becsület, képmáshoz, hangfelvételhez füződő jog az ügyvédet is megilleti hivatásának gyakorlása körében,

- ugyanakkor az ügyvéd tevékenységét kritikával illető kijelentések kapcsán jelenleg ingadozik a bírói gyakorlat a tekintetben, hogy a kijelentést véleményként vagy tényállításként értékelje, s szükségesnek tartja-e a valóság bizonyítását bizonyos véleménynek minősülő kijelentések vonatkozásában,

- a személyhez füződő jog megsértésének megállapítása esetén az ügyvéd is igényt tarthat kártérítésre, ennek körében nemcsak a szakmai pályafutásában, hanem magánéletében elszenvedett hátrányok kompenzálására is.

Leszögezhetjük, hogy a hatályos jogszabályi rendelkezésekkel majdnem teljesen összhangban áll a jelenlegi bírói gyakorlat, ugyanakkor indokolt lenne annak törvényi szintű rögzítése, hogy a nyilvános tárgyaláson eljáró ügyvéd (jogi képviselő) közszereplőnek minősül, tevékenysége nyilvános közszereplés, mellyel összefüggésben viszont kép- és hangfelvételek készítéséhez engedélyére nincs szükség.

\footnotetext{
${ }^{1}$ A szerző egyetemi adjunktus, DE-ÁJK.

${ }^{2}$ Petrik Ferenc: A személyiség jogi védelme, sajtó-helyreigazítás, HVG-Orac Lap- és Könyvkiadó Kft., Budapest, 2001.

${ }^{3}$ Tattay Levente: A közszereplők személyiségi jogai, Dialog Campus Kiadó, Budapest-Pécs, 2007., Fézer Tamás: Gondolatok az erkölcsi károkhoz kapcsolódó hozzátartozói igények megengedhetőségéről, Debreceni Jogi Mühely internetes folyóirat, 2005. október 1.

${ }^{4}$ Pribula László: A köztudomású tények értékelése a hozzátartozói nem vagyoni kártérítés bírói gyakorlatában, Jogtudományi Közlöny, 2012. július-augusztus, 288-297. oldal

5 Fézer Tamás: Ítélkezési állandók és vitás kérdések az erkölcsi kártérítés újabb magyar joggyakorlatában, Debreceni Jogi Mühely internetes folyóirat, 2004. december 1.

${ }^{6}$ Alaptörvény II. cikk.

${ }^{7}$ Alaptörvény IV. cikk. (1) bekezdés

${ }^{8}$ Alaptörvény VI. cikk. (1) bekezdés

${ }^{9}$ Alaptörvény VI. cikk. (2) bekezdés

${ }^{10}$ Alaptörvény VII. cikk.

${ }^{11}$ Alaptörvény IX. cikk.

12 T/7971. számú törvényjavaslat

${ }^{13}$ Új Ptk. tervezet Második könyv 3. rész XI-XII. cikk.

${ }^{14}$ BH 1980.83
} 
${ }^{15}$ BDT 2011.89

16 1998. évi XI. törvény

17 1998. évi XI. törvény 3. § (1) bekezdés

${ }^{18}$ BDT 2008.1737

${ }^{19}$ Tattay Levente: A közszereplők személyiségi jogai, Dialóg Campus Kiadó, Budapest, 2007, 63. oldal

${ }^{20}$ Tattay Levente: A közszereplők személyiségi jogai, Dialóg Campus Kiadó, Budapest, 2007, 64. oldal

${ }^{21}$ Fleck Zoltán: A véleménynyilvánítás határai a magyar bírói gyakorlatban, Alkotmány és Jogpolitikai Intézet, Budapest, 1966, 31. oldal, idézi: Tattay Levente: A közszereplők személyiségi jogai, Dialóg Campus Kiadó, Budapest, 2007, 65. oldal

${ }^{22} \mathrm{BH} 2004.104$

${ }^{23}$ BDT 2005.1278

${ }^{24}$ Tattay Levente: A közszereplők személyiségi jogai, Dialóg Campus Kiadó, Budapest-Pécs, 2007, 217. oldal (a Fővárosi Bíróság 48.Pf.20598/2003. számú perben hozott ítéletének elemzése)

${ }^{25}$ Tattay Levente: A közszereplők személyiségi jogai, Dialóg Campus Kiadó, Budapest-Pécs, 2007, 226. oldal

${ }^{26}$ BDT 2011.2420

${ }^{27}$ Fővárosi Törvényszék 19.P.25.489/2011/10. sorszámú ítélet

${ }^{28}$ Fővárosi Bíróság 19.P.24.721/2008/11. számú ítélet 6. oldal

${ }^{29}$ Törő Károly: A személyiség jogi védelme, Budapest, Közgazdasági és Jogi Könyvkiadó, Budapest, $1992 ., 548$. oldal

${ }^{30}$ A közszereplői „minőség” megfogalmazására nézve lásd: Dr. Sarkady Ildikó: A közszereplők személyiségvédelme a bírói gyakorlatban, www.mediakutato.hu/cikk/2006_03_osz/06_kozszereplok_szemelyisegvedelme/02.html

${ }^{31}$ Fővárosi Bíróság 19.P.26.797/2010/11. számú ítélet 6. oldal

${ }^{32}$ Fővárosi Bíróság 65.P.20.334/2011/6. számú ítélet 4. oldal

${ }^{33}$ Petrik Ferenc: A személyiség védelme, a sajtó-helyreigazítás, HVG Orac Lap- és Könyvkiadó Kft., Budapest, 2001, 87. oldal

${ }^{34}$ Tattay Levente: A közszereplök személyiségi jogai, Dialóg Campus Kiadó, 2007, 175. oldal

${ }^{35}$ Székely László: Magyar sajtó- és médiajog, Dialóg Campus Kiadó, Budapest-Pécs, 2007, 187. oldal

${ }^{36}$ BH 2002.352, BH 2004.104.

${ }^{37}$ BDT 2006.1466

${ }^{38}$ Fővárosi Bíróság 19.P.26.797/2010/11. számú ítélet 6. oldal

${ }^{39}$ Jobbágyi Gábor: Családi és személyi jog, 5. átdolgozott kiadás, Szent István Társulat, Budapest, 2005, 78. oldal

${ }^{40}$ Törő Károly: Személyiség az állampolgári jogban, Közgazdasági és Jogi Könyvkiadó, Budapest, 1979, 353. oldal

${ }^{41}$ Dr. Petrik Ferenc: A személyiség jogi védelme, Közgazdasági és Jogi Könyvkiadó, Budapest 1992. 90. oldal

${ }^{42}$ Fővárosi Bíróság 19.P.24.409/2008/19. számú ítélet 8. oldal

${ }^{43}$ Fővárosi Bíróság 19.P.24.409/2008/19. számú ítélet 9. oldal

${ }^{44}$ Fővárosi Bíróság 19.P.26.797/2010/11. számú ítélet 8. oldal és Fővárosi Ítélőtábla 2.Pf.21.888/2011/3. számú ítélet

${ }^{45}$ Szegedí Ítélőtábla Pf.II.20.746/2010. (ÍH 2011. 45.)

${ }^{46} \mathrm{BH}$ 2006. 282

${ }^{47} \mathrm{BH}$ 2000. 293

48 1952. évi III. törvény

49 1952. évi III. törvény 134/A. § (1) és (2) bekezdés

50 1952. évi III. törvény 134/A. § (3) bekezdés

51 1952. évi III. törvény 134/A. § (4) bekezdés

${ }^{52}$ BH 2004. 234

${ }^{53}$ Fővárosi Bíróság 65.P.20.334/2011/6. számú ítélet 4. oldal

${ }^{54}$ Fővárosi Bíróság 65.P.20.334/2011/6. számú ítélet 4. oldal

${ }^{55}$ Fővárosi Ítélőtábla 2.Pf.22.390/2011/3. számú ítélet 5. oldal

${ }^{56}$ BH 2000.302, Pfv. IV.21.087.2001, BH 2002.135, BH 2004.103

${ }^{57}$ Fővárosi Bíróság 19.P.24.409/2008/19. számú ítélet 10. oldal

${ }^{58}$ Fővárosi Bíróság 65.P.20.334/2011/6. számú ítélet 5. oldal 